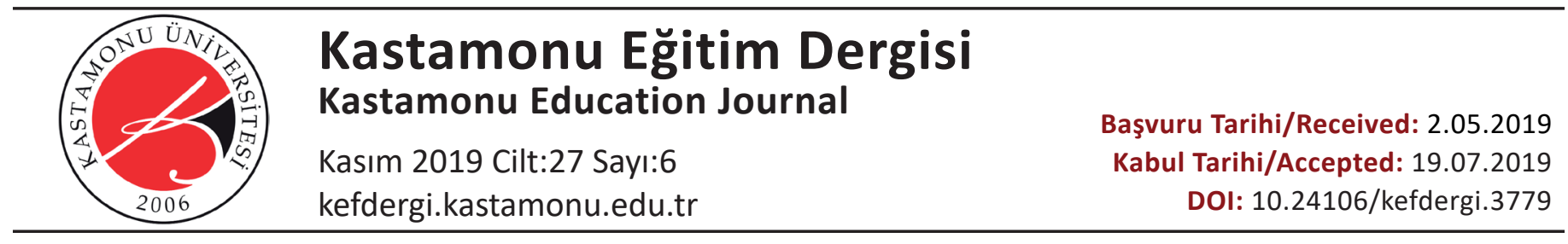

\title{
Kelîle ve Dimne’deki Etik Unsurlar; Bu Unsurların Ahlâk Eğitimi Bakımından Önemi'
}

\section{Ethical Elements in Kalilah and Dimnah; the Importance of These Elements in Moral Education}

\section{Öz}

\author{
Fatma Zehra PATTABANOĞLU²
}

"Kelîle ve Dimne" adlı masal kitabı İslâm ahlâk düşüncesinin ilk kaynaklarındandır. Hint filozof Beydaba tarafindan kaleme alınan eser, İranlı düşünür i̇bn Mukaffa tarafindan Arapçaya tercüme edilmiştir. Mezkûr eser ahlâk ve siyaset içerikli yapısının yanında, İslâmî ilimlerin oluşum aşamasında tercüme edilmesinden dolayı, ilgili dönemi aydınlatmak açısından büyük önem taşımaktadır. Ahlâkî nasihatlerle donatımış eserin amacı, masallar ve gerçek hayattan alınan hikâyelerle bireysel ve toplumsal davranışları iyileştirerek, mutlu bir yaşamın yollarını göstermektir. Buna ilaveten siyasetçilere başarılı bir yönetimin şartlarını ve pratik olarak yapılması gerekenleri öğretmektir. Makalenin amacı ise, Kelîle ve Dimne'de ele alınan ahlâkî unsurları felsefî bir çözümlemeye tâbi tutmak, ahlâk eğitimi bakımından değerlendirmek ve toplumun duygu ve düşünce dünyasını yansıtan sembolik tarzdaki bu hikâyelerin etik alanındaki etkilerine dikkat çekmektir.

Anahtar Kelimeler: kelîle ve dimne, ahlâk, siyaset, nasihat, hikmet, eğitim

\section{Abstract}

The fable book "Kalilah and Dimnah" is one of the first sources of Islamic moral thought The work, written by the Indian philosopher Beydaba, was translated into Arabic by the Iranian Thinker Ibn Mukaffa. In addition to the moral and political content of the work, it is of great importance to illuminate the relevant period due to its translation in the formation phase of Islamic sciences. The aim of the work, which is equipped with moral advice, is to show the ways of a happy life by improving individual and social behaviors through stories taken from fairy tales and real life. In addition, the aim of the work is to teach politicians the conditions of successful management and what should be done in practice. The purpose of the paper is to undertake a philosophical analysis of the moral elements discussed in Kalilah and Dimnah, to evaluate them in terms of moral education and to draw attention to the effects of these symbolic style stories reflecting the society's feelings and thoughts.

Keywords: kalilah and dimnah, ethics, politics, recitation, wisdom, education

1. Bu makalenin muhtasar hali 3.Uluslarası Sosyal Araştrmalar ve Davranış Bilimleri Sempozyumunda (20-21 Nisan 2019 Saraybosna-Bosna Hersek) sadece sözlü bildiri olarak sunulmuştur.

2. Kastamonu Üniversitesi, Fen Edebiyat Fakültesi, Felsefe Bölümü, Kastamonu, Türkiye; https://orcid.org/0000-0001-6756-8387

Atff / Citation: Pattabanoğlu, F. Z. (2019). Kelîle ve Dimne'deki etik unsurlar; bu unsurların ahlâk eğitimi bakımından önemi. Kastamonu Education Journal, 27(6), 2767-2779. doi:10.24106/kefdergi.3779 


\section{Extended Abstract}

Introduction: The author of the book "Kalilah and Dimnah", written for the Indian ruler Debshelem, is the Indian philosopher Beydeba. This work was one of the first sources of Islamic moral thought when translated from Pahlavi to Arabic by Ibn Mukaffa (d. 142/759), who had significant knowledge of Arabic, Persian, Indian and Greek cultures. The title of Kalilah and Dimnah comes from the Sanskrit name of the two jackals who are the protagonists of the fairy tale. It is known that the work influenced many people like Mevlânâ and La Fontaine. The method of writing, remarkable examples, fluent style and nice morality advice still retain its value.

Purpose and Method:The purpose of the work is to show the ways of a happy life by improving individual, social and political behaviors with advice. The purpose of the paper is to undertake a philosophical analysis of the moral elements discussed in Kalilah and Dimnah, to evaluate them in terms of moral education and to draw attention to the effects of these symbolic style stories reflecting the society's feelings and thoughts. The methods used in the study are developing hypothesis based on qualitative reading and comprehension, taking moral concepts by analyzing the stories, exploring the style of ethics based on the examples given in the work, using the analogy, inductive, deductive and descriptive methods by making holistic reading about the moral understanding.

Theme of The Work: The subject of morality is behaviors and habits. Therefore, the question of whether there will be a change of habits is accepted as one of the main issues of education. In this context, different approaches have emerged in the history of ethics. The possibility of improving our congenital characteristics through education has led to the increase of research and applications in this field. In Kalilah and Dimnah, moral concepts are presented with various examples based on knowledge and practice. In order to educate the children of the sovereigns in this work, the thoughts and acts that need to be done and to be avoided are conveyed. Therefore, the main subject of the work is the practical philosophy. The practical philosophy is about recognizing the principles that can govern the behaviors that are subject to the will of the human being and, when acting according to it, to achieve maturity. The practical philosophy that belongs to the individual is moral, to the family is familial and to the state is the political education.

In order to understand the morality in Kalilah and Dimnah in a holistic manner, we discuss it in four parts: 1. Introduction 2. Reason and wisdom, 3. Virtue and happiness; Eligibility of information and action, 4. The role of contradictory concepts in understanding of virtue and virtuelessness, 5 . Moral concepts and functions in character education. Because in this work, we see that reason and wisdom are placed on the basis of morality and, a dialectical analysis method is used with the opposing concepts. The moral concepts and the virtues are also used for character education. These virtues are 'wisdom, chastity, reason and justice'. From the explained virtues the knowledge, decorum and thought belong to wisdom. Softness, patience and dignity belong to the mind. Truth, goodness and good character are included in justice. These are good qualities for mankind, the opposite is ugly, undesirable and qualities to be avoided. According to Beydeba, who gives the rulers wise advices and forms the conditions of good people and good society, the mind is the foundation of happiness and the key to the realization of the purpose of human beings and to the virtues. However, the mind needs the right information to work well and make a correct decision. Since virtue and happiness are the main targets, knowledge and deeds are the most important parts of morality. As stated in Kalilah and Dimnah, "Science is only complete with action. Science is like a tree and its application is like a fruit. But the wise uses the knowledge to make a use of it, if the wise does not use that knowledge then you cannot call that person a scholar. If a person knows the dangerous path and follows that even so, that person is then called ignorant not a scholar."

Because the security and happiness of the public depends on the ruler in Kalilah and Dimnah, his moral characteristics perform a decisive function. For this reason, moral concepts such as wisdom, reason, prudence, softness, friendship, brotherhood, perseverance and justice have important effects on public satisfaction and power. Thus, it is possible that the society will develop in a good way and be able to get rid of the evils with the power and clever solutions. In order to gain these qualities, moral education should be given from a young age, and good behavior should be made into a habit.

Result: In conclusion, we can say that "Kalilah and Dimnah" offers a philosophical moral understanding based on virtue and wisdom. We can define the purpose of morality as individual, social and political happiness. The article frequently refers to the subject of accident and fate, but because it is always kept in mind that the personal and social problems such as the person's precaution not to leave his hand in haste, not to be hasty and not to judge on the accusation are kept in mind, the determinist view is not dominant. In some places, although examples of seclusion and mystic morality are given, it does not have a sufistic color. In fact, it is stated in the foreword that it was aimed for philosophers. 


\section{Giriş}

Kelîle ve Dimne hükümdarlara özgü olmakla birlikte, herkesin nasipleneceği eğitici ve öğretici mesajlarla donatılmış masal niteliğinde yazılmış bir eserdir. Önsözünde Hint hükümdarı Debşelim'in isteği üzerine filozof Beydeba tarafindan yazıı dığı söylenen eserin aslı, Hintçe olup Brocelman'a göre Vişnu mezhebinden adı bilinmeyen bir Brahman tarafindan, yaklaşık 300 yılında kaleme alınmıştır. Bilinen en eski adı Sanskritçe Tantrâkhyâyika'dır. ỉkinci varyantı ve bilinen en eski nüshası olan Pançatantra, bir giriş ve "insanın zekâsını kullanacağı hal" anlamına gelen "Tantra" adı verilen beş bölümden oluşur. Kelîle ve Dimne başlığı ise, eserin başkahramanları olan iki çakalın Sanskritçe adından gelmektedir (Brockelmann, 1977: 552). Sâsânî Kisrâsı Hüsrev I. Enûşirvân zamanında (531-579) tabip Berzeveyh'in (Bürzûye) Pançatantra ile birkaç Sanskritçe kaynaktan daha yararlanarak, Pehlevî dilinde tercüme edilen ve yeniden şekillenen eser, yaklaşık on yıl sonra Bûd isimli bir Hıristiyan tarafindan Süryaniceye çevrilmiştir. İran asıllı ỉbn Mukaffa da (ö.142/759) bir önsözle, Arapça'ya çevirmiştir. Belli başlı dünya dillerine yapılan Kelîle ve Dimne çevirilerinin hemen tamamı ibn Mukaffa'nın metnine dayanmaktadır. Eserin konusu genel hatlarıyla daha çok ailevî ve siyasî terbiye üzerinedir, yeri geldikçe ferdî ahlâkla ilgili örnekler mevcuttur. Sonraki asırlarda dört mukaddime eklenen kitap Mevlânâ ve La Fontaine gibi pek çok kişiye ve esere kaynaklık etmiştir (Karaismailoğlu, 2002: 210-211).

Kelîle ve Dimne hakkında literatür taraması yapıldığında çalışmaların daha çok edebiyat alanında olduğu görülmektedir. Eserin çok erken zamanlardan itibaren tercüme faaliyetleri devam etmekle birlikte, Tahirü'l Mevlevi'nin 1924 yılında "Kelîle ve Dimne eseri hakkında" başlığı ile kaleme aldığı kısa değerlendirme ilk çalışmalardan sayılabilir. Milli Eğitim tarafindan basılan İslâm Ansiklopedisinde C. Brockelmann'ın, sonra da iSAM Yayınları tarafindan hazırlanan İslâm Ansiklopesinde A. Karaismailoğlu'nun yazdığı maddeler, Kelîle ve Dimne hakkında kısa bilgi vermektedir. Batıda çeşitli ansiklopedilerde de eseri tanıtım amaçlı yazılar mevcuttur. Mesela bunlardan birisi “The Jewish Encyclopedia”dır. Eserin pekçok Türkçe çevirisi yanında Yunanca, Süryanice, Etiyopyaca, Farsça, İbranice, İspanyolca, İngilizce, Fransızca ve Almanca gibi sayısız başka dillere çevrilmesi onun edebi alandaki yaygınlığını da göstermektedir. Hatta bu tercümeler hakkında Zehra Toska "Türk edebiyatında Kelîle ve Dimne çevirileri ve Kul Mesud çevirisi" adlı doktora tezi ve "Kelîle ve Dimne'nin Türkçe çevirileri" hakkında bir makale yayınlamıştır. Feyzi Çimen'in "Meşhûr Molla Muhammed Timur'un asaru'I-imamiyye (Çağatayca Kelîle ve Dimne tercümesi) adlı eseri-metin, notlar, dizin-sözlük" başlıklı doktora tezi ve "Molla Muhammed Timur'un Çağatayca Kelîle ve Dimme tercümesi” makalesi, Yüksel Aslancan ve Kader Erdoğan'nın "Kelîle ve Dimne (transkripsiyonlu metin, lugat ve cümle tahlili)" adlı yüksek lisans tezleri, Abuzer Kalyon'un "Kelîle ve Dimne'nin tercüme serüveni", Ahmet Nahmedov'un "Kul Mesud'un Kelîle ve Dimne tercümesinde bazı arkaik kelime ve yapılar üzerine”, Hülya Azak'ın “ibnu'I-Mukaffa'nın Kelîle ve Dimne'si ile La Fontaine'nin fabllarının karşılaştırılması” vb. birkaç tane daha edebiyat alanında yazı Imış makale bulunmaktadır. Ayrıca "Kelîle ve Dimne'den Seçmeler" şeklinde kaleme alınan hikaye tarzında ya da Leyla Hasan Sa'deddin'in "Kelile ve Dimne fi'I-edebi'I-Arabi li-Ibni'I-Mukaffa" kitabı gibi çalışmalar mevcuttur. Ancak bizim konumuzla alakalı olarak görebildiğimiz kadarıyla Semra Bakan'ın, "Kelîle ve Dimne'de yer alan masalların dinî ve ahlâkî eğitime katkıları" adlı yüksek lisans tezi, Kadriye Y. Orak, Mahmut Berköz'ün "Kelîle ve Dimne tercümeleri ve kitlelerin eğitiminde rolü" makalesi dışında akademik çalışmaya rastlamadık.

İslâm ahlâk literatürünün ilk kaynaklarından kabul edilen Kelîle ve Dimne'nin, felsefenin İslâm dünyasına aktarımındaki hususi yeri ve mütercimi İbn Mukaffa'nın İslâm ahlâk ve siyaset düşüncesindeki önemi inkar edilemez. Ancak yukarıda verilen literatür çalışmasından yola çıktı̆ımızda mezkûr eserin, özellikle metin çerçevesinde ahlâk ve felsefe alanında değerlendirilmemiş olması, bizi bu açığı naçizane tamamlama yoluna sevketmiştir. Zira tek tek kavramlar bazında ele alınacak çalışmalar elbette daha şumullü ve konuyu özelleştirme bakımından daha aydınlatııı olacaktır. Ancak bir masal kitabından çıkarılacak sistematik bir ahlâk felsefesi beklentisi içinde olmak da çok isabetli olmayacaktı. Diğer taraftan da bilinmektedir ki, destanlar, masallar, hikayeler, şiirler, şarkılar, örf ve gelenekler, sanat anlayışı, yaşam tarzı ve kültürel bakış açısı bir toplumun ahlâk anlayışına dair ipuçları verir. Kelîle ve Dimne de içeriği bakımından pekçok ahlâkî unsuru barındırmakta, özellikle yalın ve etkileyici üslubuyla teorik bilgi verirken, uygulama boyutunu da eğitimcilerin istifadesine sunmaktadır. Ayrıca dikkat çekici örnekleri, kişisel ve toplumsal mesajları ve güzel ahlâkı inşa etme çabasıyla bugün dahi değerini muhafaza etmektedir. Dolayısıyla bizim bu makaledeki hedefimiz genel anlamda eserin ahlâk anlayışı bakımından değerlendirilmesi olmakla birlikte, özelde etik alanındaki yerinin ve katkısının ne olduğunun tespitidir.

Hikemiyât metinleri özünde apokrif olmakla birlikte, farklı dillere tercüme edilirken milletlerin ve dinlerin adet, gelenek ve siyasetlerine göre yeniden bir düzenlemeye tâbi olurlar. Nitekim bilgelerin ve bilge kralların hayat, ahlâk, ölüm, adâb ve siyaset gibi alanlarla ilgili sözleri sistematik olmasa da ahlâkî tecrübe birikimini gösterir (Altaş, 2016: 112,134). Her ne kadar masal ve hikâyelerden oluşsa da içeriği itibarıyla Kelîle ve Dimne hikemî eserlerden kabul edilmektedir. İran, Hind, Yunan kralları ve filozoflarının siyasete dair tecrübe ve bilgi birikimlerinin kaleme alındığı siyasetname ve nasihatnameler de siyasî gelenek haline gelmiş hikemî eserlerdendir. İslâm dünyasında bu gelenek İbn Kuteybe, Câhız, Beyhakî, Mes'ûdî, Mâverdî, Nizâmülmülk ve Gazzâlî gibi birçok siyasetname ve tarih yazarı tarafindan İslâmî yönetim 
anlayışıyla bir araya getirilmiş, hükümdar ve tebaası arasındaki ilişkiler, ahlâkî öğütlerle genişletilmiştir. İyi bir yönetim, hükümdarın bedenî ve ahlâkî gücüne bağlı olduğu için siyaset, ahlâktan bağımsız düşünülemez. Bu bağlamda siyasetnameler ve ahlâkla ilgili literatürün İslâm dünyasında gelişmesinde Kelîle ve Dimne'nin mütercimi ỉbn Mukaffa'nın önemli bir yeri vardır. Nitekim ỉbn Haldun onu, sosyolojinin öncüleri arasında sayarken, Câbirî de, İslâm-Arap ahlâkî aklının oluşumunda birinci kaynak olarak görmektedir (Kuzudişli, 2017: 59; Ateş, 1968: 865-866). Zerdüştlükten Müslüman olmuş, Fars kültürü ve siyasetini yakından bilen İbn Mukaffa, Pehlevi dilinden Arapçaya çevirdiği eserlerle, Sâsânî devlet geleneğiyle çağının İslâm anlayışı arasında köprü oluşturmuştur. Telif ve tercüme eserleri genel olarak siyaset, eğitim ve ahlâk alanlarında yoğunlaşan müellif, Grek kültürüne dair geniş bilgisiyle Müslüman ilim ve fikir adamlarının erken bir dönemde buluşmasını sağlamıştrr. Emevilerden Abbasilere geçiş döneminde üst düzey bürokrat olarak, devlet hizmetinde bulunmuş olması, i̇slâm toplumunda yaşanan problemlerin farkına varmasını sağlamış, bu problemler kendisinde ıslahatçı bir şuur ve iradenin gelişmesine yol açmıştır (Kutluer, 2000: 134-137). Döneminin genel bilgi ve kültür birikimine vakıf ibn Mukaffa'ya göre Kelîle ve Dimne dört amaca hizmet etmek için yazılmıştr: Bunlardan ilki, eğlenceye düşkün gençlerin ilgisini çekmek üzere düşünme ve konuşması olmayan hayvanların dilini kullanmak; ikincisi, hayvanların düşünce ve hayallerinin çeşitliliğinden yola çıkarak, hükümdarların gönüllerini oyalamak; üçüncüsü, kitabın hükümdar ve halk tarafindan çok benimsenmesini ve çoğaltılarak devamlılı̆ını sağlamak; dördüncüsü, özellikle filozoflara mahsus kılmaktır (ibn Mukaffa, 1990:114-117).

Fabl tarzı eserler sadece bilişsel değil, duyuşsal ve davranışsal boyut bakımından ahlâk eğitiminde önemli olmakla birlikte, zihinsel ve sosyal gelişim açısından dikkatleri çekmektedirler. Basit kurgusuyla olayların sebep ve sonuç ilişkisi içinde kısa ve yalın şekilde verilmesinden dolayı da anlaşılması daha kolay olan bu metinler, okuyucunun analiz yoluyla değere ulaşabilmesini sağlamakta, eğlenceli tekniği ile evrensel değerleri aşılama gibi önemli misyonları da icra etmektedirler (Duran, Ercan, 2018: 33). Kelîle ve Dimne'de ahlâkî-hikemî unsurların daha sonraki süreçte nasıl şekillendiğini görmek ve ferdî ahlâk yanında, felsefî ve siyasî bakış açısıyla toplumu iyileştirme adına hedeflenen perspektifi iyi okumak gerekmektedir. Nitekim etik araştrmacıları genel hatlarıyla ahlâk fenomeninin öncül nedenlerini göstermek için evren, insan ve Tanrı olmak üzere üç yola başvurmaktadır. Kelîle ve Dimne'de etiğin kaynağı bakımından, insan faktörünün öne çıktığı görülmektedir. Zira insanın merkeze alındığı bu çerçevede amaç mutluluktur. Ancak mutluluğa ulaşmanın yolu akıl ve erdemlerden geçmektedir. Bu minvalde ahlâk felsefesi bakımından eseri kritize ederken, neyi seçmeliyim? neyi yapmalıyım? ve neyi istemeliyim? sorularına cevap aradığımızda, en yüksek iyi olarak aklın ve doğru eylemin başat sayıldığını görmekteyiz. Bu sebeple akıl, bilgi-eylem ilişkisi, erdem, erdemsizlikler gibi etiğin ana konuları etrafinda şekillendireceğimiz çalışmamızda eserin eudomanist bir renk taşıdığını, göstermeye çalışacağız. Diğer yandan bir nasihat kitabı olarak kaleme alınmasından dolayı, ahlâk eğitiminin karakter üzerindeki etkilerine yer vereceğiz.

\section{Akıl ve Bilgelik}

Felsefenin (philosophia) "bilgelik sevgisi" olarak tanımlanması, pek çok yorum ve kavramı içerir ve bunlardan akıl, ilim, erdem, sevgi, samimiyet, doğruluk gibi bazılarını ahlâk bakımından öne çıkarmak mümkündür. Ahlâk, Aristoteles'ten itibaren pratik felsefede ev ve şehir yönetimiyle tamamlanan bir bütünün parçası olarak belirlenmiş ve insanî nefsle ilişkisinden dolayı, bireyin nefsinde yerleştirilmesi gereken alışkanlıklar, yani huylar olarak görülmüştür (Özturan, 2015: 5). Ayrıca olması gereken bağlamında ahlâk, iradeli ve akıllı varlığa yüklenmiş ve bir fiilin ahlâkî sayılabilmesi şartı da bunlara tâbi kılınmıştır. Nitekim ahlâk, akıllı ve bilen varlık olarak insanın hem ferdî, hem de toplumsal yapıp etmelerini kuşatan alandır. Çünkü insan özgür iradesiyle gerçekleştirdiği eylemleriyle sorumluluk alan, bilinçli bir varlıktır. Bilindiği üzere aklın bilme ve eyleme dayalı yönüyle alâkalı olarak felsefe, teorik (nazari hikmet) ve pratik (ameli hikmet) olmak üzere ikiye ayrılmaktadır. Teorik akıl, varlıklarla ilgili bilme ve varlıklar arasındaki ilişkiyi düzenleyen akıl iken; pratik akıl, teorik akıldan aldığı bilgiyi uygulama alanına yönlendiren yani fiile döken akıldır (Pattabanoğlu, 2018: 124). Kelîle ve Dimne'nin konusu da bu açıdan pratik felsefedir. Pratik felsefe de insanın iradesine tâbi davranışları idare edebilecek prensipleri tanıması ve ona göre hareket ederek umduğu olgunluğa ermesidir. Ferde ait olanı ahlâkî, aileye ait olanı ailevî, devlete ait olanı siyasî terbiyedir (Topaloğlu-Karaman, 1990: 3). Pratik felsefenin ahlâk, ev idaresi ve siyaset taksimi İslâm ahlâk düşüncesinde gelenek haline gelmiştir. (Bkz. ỉbn Sînâ, 1989:107-108; Nasîrüddin Tûsî; 2007: 26,189, 235; Taşköprîzâde, 1968, 422-428; Kınalızâde, 2012: 44-45).

Mutluluğun gerçekleşmesi için insanın kendine özgü amacının olması gerekliliği, akıl sahibi bir varlık olmasından kaynaklanır. İnsanın akla uygun eylemi, onu diğer varlıklardan ayıran en önemli özelliğidir. Etikte haz, doğa, sezgi, duygu, din gibi farklı unsurlarla temellendirilen ahlâkın kaynağı, Kelîle ve Dimne'de akıldır. Bu açıdan eserde bilinç, irade, tedbir, basiret, liyakat ve dirayet gibi kavramlar eşliğinde teorik akıl ve pratik akıl çerçevesinde ortaya konulabileceğini gösteren bir örneklem sunulmuştur. Ali b. Şah el-Fârisi adıyla bilinen Benhûd b. Sehevân, Kelîle ve Dimne'ye yazdığı önsözde, kitabın yazarı Beydeba'nın, “Hikmeti (bilgelik); dağıtmakla bitmeyen bir hazine, yoksulluğa uğramaz bir ambar, eskime bilmez bir elbise, süresi bitmez bir lezzet" olarak gördüğünü ifade eder. Nitekim İbn Sehevân’a göre insanlar için en | Kastamonu Eğitim Dergisi, 27(6), 2019| 
faydalı şeylerden biri, akıl bakımından derecesini bilmesidir (ibn Sehevân, 1990: 30-31). Dolayısıyla ahlâkî fiillerin akla ve bilgeliğe dayandııılığı eserde, iyi ve doğru bir davranışı yapma, ya da kötü davranıştan sakındırma konusunda "akıllı bir kimse şöyle yapar ya da yapmaz şeklinde örnekler verilerek, aklın önemine dair vurgu yapılmaktadır. Buna göre;

"Kişi aklıyla kendisini kontrol ederken, yine onun sayesinde ilmini geliştirir ve böylece ancak ilmi sayesinde kurtuluşa erebilir." (Beydeba, 1990: I, 250-251).

"Uysallığın işini bozduğu kimseyi, ancak ilim düzeltir. İyi adam sürçmesini itiraf eder. Bir suç işlediği zaman sözünde ve işinde doğruluğu sebebiyle terbiye olunmaktan utanmaz. Bir çıkmaza girdiğinde akıl ve maharetiyle ondan kurtulmasını bilir." (Beydeba, 1990: II, 150-151).

"Akıllı kişi yol bulacağı şeyin peşinden giderken, bulamayacağı şeyi terk eder." (Beydeba, 1990: II, 54-55).

"Kendilerine akıl ve idrak verilen, iyi ile kötüyü teşhis etme maharetine ulaştıılan, ayırt etme ve anlama kabiliyeti ile taltif edilen insanlar, birbirlerine bağlanmaya ve elbirliği yapmaya çok daha layıktır." (Beydeba, 1990: II, 84-85).

"Takva akılla, akıl tedbirli ve düşünceli davranışla beraberdir. Bütün bunların başı da basirettir." (Beydeba, 1990: II, 204-205). İşte bu sebeple aklın yol göstericiliği ile kişinin hem bireysel hem de toplumsal ahlâkî gelişmesindeki etkisini iyi vurgulamak ve bunu eğitim bakımından da doğru kullanmak gereklidir.

Beydeba'ya göre nice kavimler düşünceleriyle yani akıllarını iyi kullanarak problemlerine çare aramışlar (Beydeba, 1990: II, 108-109), hataya düşme konusunda dikkati elden bırakmamışlardır. İşte bu sebeple gerek günlük hayatta, gerek siyasî işlerde akıllı ve civanmert (ahlâklı) kimselerle birlikte olmak gerekir. Buna göre akıllı olan kişi kötü ise, onun ahlâkından sakınırken; akından istifade etmelidir. Aklı iyi olmayan civanmert kişinin ahlâkından istifade etmek gerekirken, ondan akıl almamak, ona akıl vermek gerekir. Ahmak olan kötüden ise, her iki açıdan sakınmalıdır (Beydeba, 1990: I, 242243). O halde akıllı kişi isabetli düşündüğünde korkmamalıdır, çünkü hiçbir zaman zihni ve zekâsı onu terk etmeyecektir. Ancak akıl dibine ulaşılamayan denize benzediği için, onun iyi yönde çalıştıılması gerekir (Beydeba, 1990: II, 162-163). Nitekim kişinin özel veya devlet işlerinde yapması gereken şeyler, ne zaaf ve ne de kuvvetle gerçekleşir. Burada asıl gerekli olan şey deha, akıl ve fikir gücünün isabetli olmasıdır. Dolayısıyla akıllı kişi düşmanı ile de olsa istişareyi kesmez (Beydeba, 1990: I, 188-191). Savaşlar bir devletin siyasî gelişimi noktasında önemli hususları içerir ve dirayet, akıl, nasihat, uğurlu talih gibi kavramlar zafer konusunda belirleyici olabilir. Bundan dolayı akıllı, temkinli bir adamın düşüncesi, kuvvetli, cesur, kalabalık ve hazırlıklı birçok ordudan daha tesirlidir (Beydeba, 1990: II, 130-131). Nitekim kişinin akılsal çıkarımlar yapabilmesi ve öngörülü olabilmesi, basiret ve bilgeliği gösteren bakmakla görmek arasındaki ilişkiye bağlıdır. Yani kör ve akılsız iki kişi, bakıp göremeyenlerdendir. Kör kimse, semaya, yıldızlara, yere, uzağa ve yakına bakıp göremediği gibi, aklı olmayan da güzeli çirkinden, iyilik edeni, kötüden ayıramaz (Beydeba, 1990: II, 244-245). İşte bu sebeple dünya ve ahirette insanların en bahtiyarı, Tanrı'nın kendisine akıl ve görüş nasip ettiği kimsedir (Beydeba, 1990: II, 278-279).

Yukarıdaki ifadelerden anlaşıldığı üzere Kelîle ve Dimne'de ahlâkın kaynağı akıl olmakla birlikte, bu akıl kişiye Tanrı tarafindan sunulmaktadır. $O$ halde insanın mutluluğu Tanrı'nın nasip ettiği aklın iyi kullanılmasına bağılır. Kelîle ve Dimne'nin İslâm dünyasında çok okunmasını sebeplerinden birisi belki de hikayelerdeki bu rasyonalist yapıdır. Nitekim İslâm vahyinde sık sık tekrarlanan "Düşünmez misiniz?" (Saffât, 155; Hûd, 30; Mü’minun, 85; En'am, 50; Yunus, 3 vd.), "Akıl erdirmez misiniz?" (Saffât, 138; Hûd, 51; Mü’minun, 80 vd.), "ibret almaz mısınız?" (Vâkıa, 62; Zâriyat, 4; Câsiye, 14) gibi ayetler düşünmeye sevk etmekte ve akla verilen önemin altını çizmektedir. Dinde ve ahlâkta sorumlu olan yani muhatap, akıllı bireydir. Bu çerçevede akıl, ahlâkî fiillerin kaynağı olarak verilirken, doğru ve tecrübe edinilmiş bilgi, eğitimin bir parçası olarak sunulmaktadır.

\section{Erdem ve Mutluluk; Bilgi ve Eylem Uygunluğu}

İnsan eylemlerinin son ereği olarak mutluluğu gören anlayışa genel olarak "eudaimonizm" denir ve bütün Antikçağ etiği bu karakterdedir. Bilindiği üzere mutluluğu arama yolları haz, bilgi, erdem, duygu ve kendine egemen olma, fayda gibi çeşitli biçimlerde ortaya çıkmıştır. Özellikle semavi dinler de bunun dışında değildir, hatta öteki dünyaya olan inançtan dolayı sonsuz mutluluğu amaç edinme söz konusudur (Akarsu, 1998: 23). Felsefî düşüncede gerçek mutluluk, teorik ve pratik olmak üzere her iki açıdan yetkinliğin sağlanması ile mümkündür. Bunlardan pratik kısmın zayıflığı, irade zayıflğına işaret eder ki, irade zayıflığının nedeni de ahlâk alışkanlığının az olmasıdır. Dolayısıyla övülmüş fiilleri tekrar ederek huy haline getirmek; erdemli karakter ve meleke kazanmak için de onları alışkanlık edinmek gerekmektedir (ibn Miskeveyh, 2017: 69-70). Etik ile ahlâk arasında belirgin bir ayrımın yapılmadığı dönemlerde erdem ve mutluluk bakımından en yüksek iyiyi konumlamaya çalışmak çok sık rastlanan bir durumdur. Ahlâksal erdemler iyinin gerçekleştirilmesi için, kişinin sahip olması gereken bilgi, beceri, kapasite ve yeterlilikler bakımından değerlendirilmektedir. Platon'un kendine hâkim olma (iffet), cesaret, bilgelik ve adalet olarak başlattğı erdem öğretisi (Özlem, 2010: 36-39), Aristoteles tarafindan 
devam ettirilmiştir (Aristoteles, 2007: 27, 29, 37, 93). Galen'in de nefsi erdemlerle alakalandırması, onun üç gücüne karşı üç erdemi göstermesi ve adaleti bunların uyumu veya dengesi kabul etmesi İslâm ahlâk düşüncesinde takip edilen bir gelenek haline gelmiştir (Fahri, 2004: 95-97). Hint ve İran düşüncesinde de bu geleneğin tesirini görmek mümkündür. Nitekim İbn Sehevân Kelîle ve Dimne'ye yazdığı önsözde, Beydeba’nın canlılar arasında insana mahsus dört şey gördüğünü söyler. Bunlar, "hikmet (bilgelik), iffet, akıl ve adalettir". Mezkûr erdemlerden ilim, edep ve düşünce hikmete; hilm, sabır ve vakar akla; doğruluk, iyilik, murakabe ve güzel huy ise adalete dâhildir. Bu erdemler insanlık için güzel vasıflardır, zıtları ise çirkindir ve istenilmeyen kaçınılması gereken niteliklerdir (İbn Sehevân, 1990: 28-29).

Erdem öğretisiyle ilgili olarak, bilgi-eylem ilişkisi hatırlamamız gereken diğer bir husustur. Bu hususta Sokrates'in "doğru bilgi, doğru eylem gerektirir" sözü (Platon, 2010: 47), kendisinden sonraki etikçilerin bilgi ve eylem ilişkisine bakışını şekillendirmiştir. Nitekim bu söyleme göre bilgi yönünden doğru olan, ahlâk yönünden de iyidir. Ancak ahlâkın bilinmesi, onu kazanmaya ve gerçekleştirmeye yeterli midir? şeklinde gelişen sorgulamalar, teorik bilgiyi pratiğe dönüştürme şartlarını kapsamlı bir şekilde değerlendirmeyi gerekli kılmıştır. Bu bağlamda eğitim, felsefe, etik, psikoloji, sosyoloji gibi alanlarda pek çok çalışma yapılmıştır. İbn Mukaffa da bu meseleyle ilgili olarak, Kelîle ve Dimne’yi baştanbaşa okuyup anlamanın insanın kendisini geliştirmesi bakımından yeterli olmayacağını söylemektedir. Asıl olan şey yazılanların okuyucuya örnek olması ve öğrenilen bilgilerin faydaya dönüşmesi için uygulamaya geçirilmesidir. Zira ilim-amel uygunluğu, ahlâkın en önemli kısmıdır. Mezkûr eserde de belirtildiği üzere, "ilim ancak amel ile tamam olur. İlim ağaç, onu uygulamak ise meyve gibidir. İlim sahibi ancak faydalanmak için onu kullanandır, eğer bildiğini uygulamazsa o kişiye âlim denilemez. Eğer bir kimse tehlikeli yolu bilse ve bildiği halde o yolda gitse, ona âlim değil, cahil denilir." (ibn Mukaffa, 1990: 95-99). İslâm ahlâk düşüncesinin ilim-amel uygunluğu ve gaye konusu, Kelîle ve Dimne'de dikkat çeken önemli hususlardandır. Buna göre insan bir amaç uğruna çalışmalı ve sınıra varınca durmalıdır. Zira bir amacı olmayan kişi eylemlerinin sonunda yorulacak ve istenilen şeye de ulaşamayacaktır. İnsana yakışan sınırsız şey, kendisinden önce hiçbir kimsenin elde etmediği bir şey peşinde kendisini yormaması, bunun için üzülmemesidir. Hedefi olan kişi geçim, toplumsal münasebetler ve ölümden sonra iyi anılmayı sağlayacak ameller konusunda hayatını düzene koymalıdır. Tembellik ve ihmal, firsatları kaçırma ve her haber getirene inanma hayat düzensiz yapan ve istenilmeyen davranışlardır (Beydeba, 1990: I, 101-105). Söz güzelliği de ancak davranış güzelliği ile tamamlanır. Derdinin devasını bilen hasta onunla kendini tedavi etmezse, meseleyi bilmiş olması hiçbir fayda sağlamayacaktır (Beydeba, 1990: II, 72-75).

İtidal ve denge anlamına gelen adalet, Kelîle ve Dimne'de insan fiillerinin merkezini işgal etmektedir. Nitekim Hint ve İran gelenekleri arasındaki etkileşimin diğer düşünceler üzerindeki etkisinin, "daire-i adalet" bağlamında Kelîle ve Dimne üzerinden gerçekleştirildiği düşünülmektedir. Aristoteles'te erdemlerin toplamı olarak kabul edilen adalet, Beydeba'ya göre siyasetin temelidir. En hayırı hükümdar da adaleti sağlayandır. Nitekim baskı ve zulmü engellemek ancak kendisiyle mümkün olacağı içindir ki siyaset, halkı hoşnutsuzluğa sebep olmadan egemenliği korumanın tek yoludur. Siyasetin temeli olan adalet ise, tarafsızlık ve akıl ile var olur (Uçar, 2012: 6-7). Bütün pratik ahlâk ve siyaset kitaplarının amacı, hikmetli vecizelerle insanlara mutlu bir yaşamın yollarını göstermek ve bilhassa hükümdarlara başarılı bir idarenin sırlarını ve pratik kaidelerini öğretmektir. Bu eserler ahlâkî unsurları da içerdikleri için, fert ve toplum bakımından olması ve yapılması gerekenleri verirler. Aynı amaçlara sahip olan Kelîle ve Dimne'de ahlâkî fiilin tek sahibi insandır ve bundan dolayı insandan üstün hiçbir varlık yoktur. Ancak insanların içinde, iyi ve kötü olanlar vardır (Beydeba, 1990: II, 256-257). Adalet, iyilik edenin fiilinden kötülük edeninkini ayırt etmek ve zıddı olan zulümden kaçınmak, insana hakkı olan şeyi vermek, hakkı olmayan şeyi de vermemektir. Nitekim insandaki beş huy, kendisine dost kazanmasını ve iyi firsatlar elde etmesini sağlar. Bunlar "kimseyi incitmemek, terbiye görmüş olmak, şüphe ve töhmetten uzak durmak, iyi ahlâk, davranışlarda olgunluk ve asalettir". Beydeba'ya göre servetin en kötüsü harcanmayan, eşlerin en kötüsü itaat etmeyen, evladın en kötüsü ana babasına asi olan, arkadaşların en kötüsü felaketler ve sıkıntılarda arkadaşını terk eden, hükümdarın en kötüsü suçsuz kimselerin kendisinden korktuğu zalim ve halkını korumaya devam etmeyen, memleketlerin en fenası bolluk ve emniyet olmayandır (Beydeba, 1990: II, 188-189). Hükümdarın en hayırlısı adaletli olandır. Adaletin olduğu yerde iyilik, bolluk ve neticesinde mutluluk vardır.

Siyasetnamelerde hükümdarın şahsında ele alınan ahlâkî unsurlar, bireylerin ahlâka bakışına da yön verir. Hükümdar temkinli, dirayetli, becerikli, mutluluğun şımartmadığı, felaketin korkutmadığı bir karaktere sahip olmalıdır. Bununla beraber işlerini gerektiği zaman yumuşaklıkla, gerektiğinde sertlikle yapmalı, öfke, rıza, sürat ve teenni zamanlarını bilmeli, hem bu gününü, hem yarınını düşünmeli ve işinin neticelerini önceden görmelidir (Beydeba, 1990: II, 130-131). Siyasî açıdan yöneten ve yönetilenin konumları farklı olmakla birlikte, ahlâkî bakımdan benzer ilkeler diğer insanların da eylemlerini ve ahlâkî durumlarını şekillendirir. Bir şeye karşı tahammül göstermeye insanı sevk eden en önemli amil, kişinin kendi nefsidir. Kişinin nefsini eğitmesi ve terbiye etmesi, ahlâkî özelliklerini iyileştirmede öncelikli adımlardandır. Ahlâkî özellikleri bakımından iyi ve güzel olmak hükümdar ve halk için şöyle özetlenebilir: "Akılılık, tedbirli olmak; takva, eziyet etmekten sakınmak; asalet, güzel ahlâk; zenginlik, kanaat demektir." (Beydeba, 1990: II, 70-71). Bu özelliklerle 
yetkinleşmiş kişiler iyilik, yüce ruhluluk, sözüne bağlılık, kadirşinaslık, vefakârlık, halka karşı sevgi, kıskançlıktan kurtulma, eziyet etmekten uzak kalma, yükleri ağır da olsa dost ve arkadaşlarınkini taşıma meziyetlerine de sahiptir. O halde onları örnek alıp, birlikte zaman geçirmek ve terk etmemek ahlâk eğitimi bakımından önemlidir. Diğer taraftan huysuz, sözünde durmayan, nankör, vefasız, zalim ve Allah korkusu olmayan, ahiretin sevap ve cezasını inkâr eden kimselerden ise uzak durmak, onların huylarını beğenmemek, kendi fiillerimizde de bunların olmaması için çaba göstermek gereklidir (Beydeba, 1990: II, 206-207).

Kelîle ve Dimne'de mutluluk, bilgeliğe dayandırılan bir amaca yöneliktir. Ferdi ve toplumsal mutluluğun hedeflendiği eserde insanın bir amacının olması gerektiğine vurgu yapılmaktadır. Bu bağlamda insanın amaçlarını gerçekleştirmesinde irade faktörü önem arzetmektedir. Eserde insanın iradesi, kader konusuyla ilişkili ele alınmıştrr. Nitekim insanın mutluluğu bir bakıma kaderine bağlıdır. Beydeba'ya göre hayır ve şer önceden planlanmış bir kader üzeredir. Bu sebeple insana takdir edilen ne olursa olsun onun başına gelir. Kaderi kimse yenemeyeceğine göre, kaza ve kadere sabretmek ve onların neticesini beklemek işlerin en iyisidir (Beydeba, 1990: II, 52-53, 270-271, 212-213). Ancak kader konusu, intiyatı kimseyi tehlikelerden kaçınmaktan ve istenmeyen şeylerden korunmaktan men etmez. Aksine böyle kimse kadere inanmakla, tedbiri ve işlerinde kudretli olmayı birleştirmiş olur (Beydeba, 1990: II, 184-185, 276-277). Nitekim her kim lokmasını ölçmez ve ağzına sığmayacak kadar büyük alırsa, onu yutamayıp boğulabilir. Düşmanın sözüne aldanan ve tuzağına düşen ve ihtiyatlı davranmayan kişi, kendisine düşmanından daha düşmandır. $O$ halde yapılması gereken kişinin kendisine ne getireceği belli olmayan kadere bakıp işini ona göre ayarlaması değil, ihtiyatlı olması, tedbiri elden bırakmaması, gücünü kullanması ve nefsini hesaba çekmesidir (Beydeba, 1990: II, 186-187). Tanrı dünyayı, ahiretin vesilesi ve doğrulayıcısı kılmıştır. Çünkü dünya ilahî elçiler ve peygamberler yurdudur. Onlar hayra delalet eden, cennete kılavuzluk yapan ve Tanrı'yı bilip tanımaya davet eden kimselerdir (Beydeba, 1990: II, 36-37). İşte bundan dolayı akının kılavuzluğundan faydalanan insanın sorumluluklarının farkında olması, mutlu ve güçlü toplum içinde yaşamak için, birlik fikriyle hareket etmesi gerekmektedir (Beydeba, 1990: II, 50-51). Böylece etiğin en önemli konularından biri olan irade meselesi de açığa çıkmış olmaktadır. Buna göre insan ilahî bilgiyle doğru ve yanlışı bilmesi ve aklı sayesinde seçimlerini gerçekleştirmesinden dolayı, kendi fiillerinin sonuçlarından sorumludur. Ancak doğanın bir parçası olarak insan, kendi sorumluluğu dışında meydana gelen birçok konunun da öznesi olabilir. Dolayısıyla insan mutlak bir özgürlüğe sahip olmasa da, aklî seçimlerinden dolayı özgür sayılır.

\section{Erdem ve Erdemsizliğin Anlaşılmasında Zıt Kavramların Rolü}

İslâm felsefesinde erdemler itidal teorisi ekseninde değerlendirilmiştir. Erdemler ve erdemsizlikler (faziletler-reziletler) yukarıda anlattı̆ımız, bilgelik, iffet, cesaret ve bunların toplamı hâlindeki adaletten oluşan erdem anlayışı ile ilk üç erdemin aşırılıkları (ifrat ve tefrit) olan erdemsizliklerden oluşmaktadır. Tıpkı Sokrates ve Aristoteles'te olduğu gibi İslâm dünyasında da genellikle ahlâk felsefesinin temelini erdem anlayışı oluşturmaktadır. Bu sebeple erdem ve erdemsizlik olarak temel iki zıt kavram, diğer ahlâkî kavramların kendi bünyesinde anlaşılamasını sağlamaktadır. Kelîle ve Dimne'de de erdemlerin ve erdemsizliklerin bu şekilde zıt kavramlar tarafindan açıklandığını görmekteyiz. Nitekim bir kavram hakkında ayrıntılı bilgi sahibi olmak istediğimizde, onun zıt anlamına başvurur ve farklı açılardan meseleyi kavramaya çalışırız. Zitra bazı kavramlar karşıtları bilinmedikçe yeterince ve açık anlaşılamaz. Bu sebeple bazen kelimenin eş anlamından ziyade, zıt anlamının aydınlatıı olduğunu görürüz. Dolayısıyla soyut ve somut kavramlar, zıtlarıyla daha iyi anlaşıldığı için, Antik Yunandan beri zıtlıkların kozmosta ve varlık alanındaki etkisi tartşıımaktadır. Bu süreçte zıtların çaţşması ve neticesinde ortaya çıkan uyum ya da değişim, diyalektik yöntemle ele alınmıştı. Nitekim Anaksimandros'ta evren karşıtlardan ve zıtlıklardan meydana gelmektedir. Pythagorasçılar’a göre uyumu meydana getiren şeylerden biri, zıtlıklardır. Evrende zıtlar arasında sürekli bir mücadele olduğu düşüncesini ilke haline getiren Herakleitos da bir olanın birliğini meydana getiren şeyi, çok olanın zıtlar gerilimi olarak tasvir etmektedir (Arslan, 2011:111, 153,192).

Filozof Beydeba Kelîle ve Dimne'de gerek meselleri çoğaltmak, gerek konuyu daha anlaşılır kılmak için kavramların zıtlıklarından yola çıkarak, yeri geldiğinde diyalektik yönteme başvurmaktadır. Böylece yapılması ve yapılmaması gerekenler, örneklerle ve öğütlerle sonuç odaklı olarak sunulmaktadır. Nitekim hikâyenin başında zıtlık oluşturan iki hayvanın karşıt karakterlerine işaret edilmektedir. Buna göre Kelîle, sınıfindan memnun olan kanaatkâr insan karakterini, Dimne ise ihtirasları uğruna her şeyi yapabilen, layık olmadığı hâlde sınıf atlama peşinde koşan insan karakterini temsil eder. Böylece insanlar arasındaki sınıf farkı ve insanın kendi bulunduğu sınıftan memnun olması gerektiği, hayvanlar vasıta kıınarak alegorik bir şekilde ispat edilmeye çalışıır. Eserdeki bu karşıtık, Hindistan'daki kast sisteminin bir yansıması olarak da yorumlanabilse de (Orak-Berköz, 2013: 224), bu sisteme dair herhangi bir anekdot geçmemektedir. Daha çok nasihatnamelerde olduğu gibi öğütler, hem siyasî hem de ahlâkî gelişim bakımından ele alınmaktadır. Böylece iyi-kötü, âlim-cahil, yalan-doğru, cömert-savurgan, dost-düşman, çalışkan-tembel gibi zıt kavramların vurgusuyla ahlâkî unsurlar değerlendirilmekte, davranışlara dair niteliksel farklııklar sunulmaya çalışılmaktadır. Ahlâkî eğitimin amacı iyi davranış 
kazandırmak ve bunu alışkanlık haline getirmektir. Bu sebeple düşüncenin pratiğe geçirilmesi ve devamlılığın sağlanması için zıt kavramların doğru anlaşılmasında fayda vardır. Nitekim "iyilikler kötülükleri giderir" (Hûd,114) ayetinde de vurgulandığı üzere zıtlıkların birbirini yok etme ya da bir davranışı zıddıyla pekiştirme durumu, eğitim metodu olarak kullanılmaktadır. Tıp ilminde hastalığın zıddıyla ortadan kaldırılması gibi, aynı metodun nefsler için de geçerli olduğunu iddia eden İran asıllı Nasîrüddin Tûsî’ye (ö.1274) göre, nefsin tedavisi erdemsizlikleri ortadan kaldırmakla mümkündür. Öyleyse tedavide yapılacak ilk şey, nefsin bu halinin sebebinin bilinmesidir. Sonra akli irade ile kötülüğe sevk eden erdemsizliklerden kaçınmalı, zıddı olan erdeme başvurarak güzel fiilleri tekrar etmelidir. Bu tedavi ile problem çözülmezse nefs fikir, söz veya eylemle azarlanmalı, kınanmalı ve sitem edilmelidir. Böylece nefsin öfke ve şehvet güçlerindeki dengelenme yetersiz olunca diğer düşünme gücüne firsat verilmiş olur. Bu da fayda vermezse dengelenme şartının korunmasıyla birlikte erdemsizlik sebepleri araştırııp, en üstün geleni bastırımalıdır. Bu uygulama da yetersiz olursa, nefsi cezalandırmak, zor işler yaptırmak ve önceki alışkanlıklarından sonra zor görevler vererek eğitmek gereklidir (Nasîrüddin Tûsî, 2007: 149,151-153). Zıtlıklardan yola çıkarak ahlâk eğitimine atıf yapan Osmanlı âlimlerinden Taşköprîzâde (ö.1561) de cehaleti, zıddı olan ilimle tedavi etmek gerektiğini; bu tedaviyi uygularken ilim meclislerinde oturup, ince manaların araştııldığı müzakere ortamlarında bilgelerle birlikte vakit geçirmek gerektiğini söyler. Buna göre bedensel hastalıkların tedavisi nasıl zıddıyla yapılıyorsa, kibrin tevazuuyla, açgözlülüğün kanaatle, öfkenin hilmle, hasedin içten olmayla tedavi edilmesi gibi, ahlâkî problemler de eğitimle düzeltilmesi mümkündür (Taşköprîzâde, 2014: 116,123; 2016:112-113).

Kelîle ve Dimne'de ahlâkî özellikler bağlamında zıt olanlara baktığımızda öncelikle "iyilik ve kötülük" kavramlarına dikkat çekildiğini görmekteyiz. Buna göre insan sebep ve sonuç bağını düşünmeden, yanlış adımlar attğı sürece kötülüklerle karşılaşır. O halde iyilik ve kötülük bireyin kendi seçimlerine dayanır. Zaten dini bilgiye göre kötülük problemi konusunda Tanrı'yı insanın başına gelen kötülüklerde yakın sebep olarak görmek, doğru değildir. Tanrı, iyinin karşısında kötünün varlığını sürdürmesine müsaade ediyorsa, bu müsaadeyi, insanların başına gelen musibetlerde uzak bir sebep olarak nitelenebilir. Zira musibetler daha çok insanların inmal ve aceleciliklerinde yatmaktadır (Saruhan, 2002: 553). Kelîle ve Dimne'de iyilik ve kötülük konusu, zaman zaman kaderle bağlantılı olarak ele alınsa da, insanın aklı, seçimleri ve tedbirine dayanan bir irade durumu söz konusudur. Beydeba'ya göre, "Kötünün şerrinden kimse salim kalamaz. Eğer o kimse, bizzat kötülük yapmaktan aciz olsa da, şer yine kendi sebebiyle gelir. Kötülerle arkadaş olmak, çoğu zaman kişide iyilere karşı suizan beslemeye sebep olur." (Beydeba, 1990: I, 206-207, 214-215). Kötü kimse layık olmadığı mevkiye getirilirse, yükselinceye kadar faydalı olur ve hep daha fazlasını ister, sadece korkudan hükümdara hizmet ve hayır duada bulunur. Ama korkusu gidince aslına döner (Beydeba, 1990: I, 202-203). Bir kimse kötülüklerini bildiği halde onlarla birlikte olmaya devam ederse, kendine eziyet etmiş olur. Bu sebeple zahitler halkla oturup kalkmaktan vazgeçerek, yalnızlığı insanlarla birlikte olmaya, ibadeti de dünya sevgisine tercih etmişlerdir. İyiliği iyilikle, güzelliği güzellikle karşılayan Tanrı'dan başka kimse yoktur. İyiliğe karşı mükâfat bekleyen kişi mahrumiyete uğrar (Beydeba, 1990: II, 10-11). Bu sebeple asıl iyilik karşılık beklemeksizin yapılandır. İslâm düşüncesinde "Ameller niyetlere göredir" (Buhârî, "Bedü'l-vahy", 1) hadisi bu açıdan değerlendirilmelidir.

"Düşman ve dost" zıtlı̆ıını doğru anlamak ise, hem siyasî hem de ahlâkî davranışları değerlendirmek bakımından önemlidir. Kelîle ve Dimne'de dostların en iyisi nasihat eden, amellerin en hayırlısı akıbeti en iyi olan, övgünün en hayırlısı iyilerin ağzından gelen, hükümdarların en hayırlısı şımarık olmayan, huyların en hayırlısı takvaya en çok yaklaştırandır. Hükümdarın en âcizi ağır davranan, işlerin geleceğini az düşünen, kötü şeylere üzülmeyen, elden kaçırılan firsatlar için başkalarını suçlayandır (Beydeba, 1990: I, 204-205). Kişinin dostunu ve düşmanını iyi bilmesi yeri ve zamanına göre uygun davranışta bulunması gereklidir. Bu sebeple kendisine yardımcılar bulabileceği ihtimaliyle, zayıf ve hakir sayılan düşmanı küçümsememelidir (Beydeba, 1990: I, 230-231). Nitekim düşmanın en şiddetlisi aslî ve tabiî düşmanlıktır. Fil ile aslanın düşmanlığında birbirine denk düşmanlık olduğu gibi, güçler arasında dengesizliğin olduğu türler de vardır. Akıllı kişi, zeki ve kurnaz düşmanıyla dostluk kurmaz. Dost olmanın belirtilerinden biri, dostunun dostuna dost olmak, düşmanına düşman olmaktır (Beydeba, 1990: II, 54-59). Zira arkadaşına ve dostuna kötülük yapan kimsenin, herkese kötülük yapacağı düşünülür. Bundan dolayı vefasız olan kişiye gösterilen sevgi, teşekkürü olmayan kimseye yapılan lütuf, nasihat kabul etmeyen kimseye sarf edilen terbiye, sır tutmayana verilen sır kadar boşuna harcanmış bir şey yoktur. İyilerle yapılan dostluk iyilik, kötülerle yapılan dostluk da kötülük getirir (Beydeba, 1990: I, 244-247). (Hikâyelerdeki karakter tahlilleri için bkz. Bakan, 2006: 24-188).

"Cahillik-bilgelik", "güçlülük-zayıflı", "hilm-sertlik" gibi zıt kavramlar da hükümdarın ahlâkını ve onun şahsında diğer insanları ilgilendiren durumları bize gösterir. Nitekim hükümdarın iyi giden yönetimi mahrumiyet, fitne, nefsanî arzulara kapılma, kabalık, zaman, cehalet ve ahmaklık ile bozulur. Bunları açmak gerekirse mahrumiyet, yönetimde fikir sahibi, cesur ve güvenilir yardımcılardan, nasihatçilerden yoksun olmak anlamına gelir. Fitne, tebaanın birbiriyle cedelleşmesi ve aralarında anlaşmazlık olması; nefsanî arzular kadınlara düşkün olma, sohbete eğlenceye, içki vb. şeylere kapılma; kabalık şiddet göstermek ve dilin sövmesi, elin dövmekle azmasıdır. Zaman ise hayvanların telef olması ekinlerin eksilmesi, savaşların çoğalması, felaketlerin artması; cehalet ve ahmaklık ise, yumuşak olacak yerde şiddet göstermek, 
şiddet gösterilecek yerde yumuşak olmaktır (Beydeba, 1990: I, 186-187). "Yumuşaklık ve sertlik" gibi iki zıt kavramın, zamanında ve yerinde, olması gereken kadar gösterilmesi ahlâkî bakımdan olduğu kadar, siyasî iktidar bakımından da önem arz etmektedir. O halde kibirli olan kimse güzel övgüye, yalancı ve aldatıcı kimse fazla dost sahibi olmaya, terbiyesiz kimse şerefe, hasis olan cömertliğe, ihtirasa kapılan kimse az günahkâr olmaya, olayları önemsemeyen ve yardımcıları zayıf hükümdar da saltanatının devamlılığına ve halkının refah ve düzenine tamah etmemelidir (Beydeba, 1990: II, 126-127). İşte bütün bunlar, zıtlıklar içinde denge ve uyuma, "doğru ve yanlış", "hak ve batll", "adalet ve zulüm" karşısında olması ve yapılması gerekene işaret etmektedir.

Düşünce tarihinde "nefs (ruh) ve beden" zıtlığı felsefe, ahlâk ve tasavvufta sık sık kullanılagelmiştir. Bu kavramlar birbirinin karşıt olarak görülmekle birlikte aralarındaki denge ve uyum, gerek beden gerek ruh sağlığı bakımından insanın iyiliğini ve mutluluğunu belirlemektedir. Dolayısıyla bir kimse kendisini hasta edip eziyet veren şeyin, kendi bedeninden kaynaklandığını bilmeli, ona göre hareket etmelidir (Beydeba, 1990: I, 170-171). Kişi nefsini eğitme ve terbiye konusunda en büyük zarar vericinin önce kendisi olduğunun farkına varmalı ve buradan hareketle önce kendi düşüncesini iyileştirmelidir (Beydeba, 1990: I, 84-85). İnsan toplumsal bir varlık olduğu için yardımlaşmayı, fedakârlığı ve paylaşmayı ilke haline getirmelidir. Zira servet sahibi kişi aynı zamanda erdemli olup, aile, kardeş ve arkadaşlarına verimkâr davranırsa kısa ömrü, uzun sayılırken; yalnız karnını doyurup buna kanaat eden kişi, hayvanlardan sayılır. İnsanlar arasında mevkiler mücadeleye konu olabilecek mertlik derecesine göre farklılık arz edebilir. Unutulmamalıdır ki, şerefli mevkiye yükselmek güç, ama oradan düşmek çok kolaydır. Taş gibi onu omuza çıkarmak güç, ama yere bırakmak kolaydır. iktidara gitmek zor, ama orada kalmak daha da zordur (Beydeba, 1990: I, 160-161,166-167). Ancak insanların toplumdaki konumları, onların karakterleri hakkında önyargılı bir tutuma sebep olabilir. Mesela fakir kişiye cesur ise deli, cömert ise müsrif, uysal ise aciz, vakur ise ahmak derler (Beydeba, 1990: II, 68-69). Hâlbuki bu kişi zengin olsa bu vasıfların muhtemelen tersi doğru kabul edilecektir. İște yukarıdaki ifadelerden anlaşılacağı üzere filozof Beydeba'nın hikmetli sözleri zıt kavramları kullanarak anlatması ve bunları kendine özgü bir metotla vermesi, gerek eğitim gerek bilgilendirme bakımından okuyucunun hayal gücünü genişletmekte, farklı perspektiflere olanak tanımakta ve ahlâkî unsurların anlaşılmasında alternatif yaklaşımlar sunmaktadır.

\section{Ahlâkî Kavramların Karakter Eğitimindeki Fonksiyonları}

Karakter eğitimi konusunda yapılacak etkinliklerin erdemlerde mi, değerlerde mi, davranışlarda mı yoksa mantık kapasitesinde mi olması gerektiği noktasında farklı bakış açıları bulunmaktadır. Ancak problemin çözümünde öncelikle kişinin şahsi özellikleri ve psikolojisinin iyi tanımlanmasına ihtayaç vardır. Nitekim karakter kavramı "kendisinin ahlâki olarak işlev görme eğilimini ve yeteneğini etkileyen psikolojik özellikler dizisi" olarak tanımlandığı zaman, en temel yaklaşımla kişinin doğru olanı yapıp, yanlış olandan sakınması gerekliliği ortaya çıkmaktadır. Ahlâklı insanın tamamlanmasını sağlayan psikolojik bileşenleri ise ahlâki davranış, ahlâki değerler, ahlâki kişilik, ahlâki duygular, ahlâki muhakeme, ahlâki kimlik ve kurucu özelliklerdir (Berkowitz, 2014: 285, 289). Bu çerçevede sözlük anlamı itibarıyla yaratılış, huy, karakter, seciye, din ve âdet anlamına gelen ahlâk (Çağrıcı, 1989:1) da, konusu itibarıyla davranış ve karakteri (huyları) kapsamaktadır. Bundan dolayı karakterin değişip değişmeyeceği konusu ahlâk ve eğitim alanlarının birlikte müzakere edeceği bir meseledir.

Etik sözcüğünün karakter bilimini dile getirdiği (Akarsu, 1998: 120) Aristoteles'e göre, düşünce ve karakter olmak üzere iki tür erdem vardır. Bunlardan düşünce erdemi daha çok eğitimle oluşup, gelişirken karakter erdemi alışkanlıkla edinilir. Bundan dolayı karakter erdemleri doğuştan değildir; erdemleri elde edebileceğimiz doğal bir yapımız vardır ve bunları alışkanlıkla tam olarak geliştirebiliriz (Aristoteles, 2007: 29-30). Erdeme olan doğal yatkınlık ve ahlâkî bilgi ne kadar erdeme dayanırsa dayansın, erdemin özü erdemli eylemle ortaya çıkar. Bu eylemle ilkin özgür kararla yapılan şey, sonradan alışmayla yapıla yapıla karakter halini alır. Böylece ahlâk öğretilerinin öğrenilmesi davranışı, alışkanlığı ve istencin bilgiden önce olmasını gerektirir (Akarsu, 1998: 134). Diğer taraftan ahlâk eğitimi konusunda farklı görüşler olmakla birlikte "karakter mizaca dayanıyorsa değişimi zordur ama imkânsız değildir" anlayışı, doğuştan getirdiğimiz özelliklerimizin tamamen olmasa da eğitimle değiştirilmesinin imkân dâhilinde olduğunu göstermektedir. Kelîle ve Dimne'de ahlâkî kavramlar bilme ve uygulamaya dayalı olarak ve karakter eğitimini mümkün gören bir anlayışla sunulmaktadır. Nitekim hükümdar çocuklarını eğitme amaçlı yazılan eserde yapılması ve uzak durulması gereken düşünce ve fiiller nakledilmektedir. Hikayelerdeki karakterler üzerinde psikolojik tahlil yapmaya imkan veren unsurlar, kişisel gelişim bakımından da yapılması gerekenleri göstermektedir. Eserde karakter eğitimini ya da ahlâki gelişimi anlatan örnekler genelde doğruluk, emanet, sabır, şükür, metanet gibi temel ahlâki kavramlara dayanmaktadır. Ancak eser eşlerin en kötüsünü kocasına itaat etmeyen olarak görmesi, yada akıllı kişinin kızları düşman bilmesi gerekliliği gibi günümüzün toplumsal cinsiyet kavramı bakımından eleştiri alabilecek düşünceleri de içermektedir (Beydeba, 1990: II, 178-179, 188-189). Bu minvalde aşağıda verilen ahlâkî kavramlar, öğütlerden çıkarılmıştır ya da hikâyelerdeki tecrübelere dayanmaktadır. 
Sorumluluk; Bir dine dayansın ya dayanmasın ahlâkî öğreti yükümlülük, sorumluluk ve müeyyide olmak üzere üç saç ayağına dayanmaktadır. Bu saç ayağının üzerine oturduğu temel de kökü insan fitratında bulunan adalet fikridir (Turhan, 1996: 23). Nitekim toplum içinde düzenli bir yaşam, kişinin üzerine düşen görevleri yapmasıyla gerçekleşir. Bundan dolayı insanlar kendi sorumluluklarını yapmazlarsa, hiçbir değer taşımazlar. Sorumluluklarını bilmeyen kimseler kum koyacağı yere kül koyan, misafir olduğu halde ev sahibi olduğunu söyleyen, toplumda kendi işi olmayan şeylere karışan, kendisine sorulmayan şeylere cevap veren kimseler gibidir. Onlar insanların hallerinden anlamazlar ve kötülüğü kendilerinden uzaklaştramazlar (Beydeba, 1990: II, 16-17).

Sabır ve sebat; Hatadan korunmak için, herkes işini ölçüp tartmalı, acele etmemeli, sabır ve sebat göstermelidir (Beydeba, 1990: II, 158-159). İşlerde sebat göstermek başarılı ve mutlu olmak bakımından çok önemlidir. Bu sebeple "Bir işin ya da bir dileğin peşinde koşmak onu elde ettikten sonra, korumaktan daha kolaydır." (Beydeba, 1990: II, 138139) sözünü düstur edinmek gereklidir.

Cömertlik; Servet sahiplerinin servetlerini Allah yolunda ve ihtiyaç halindeki kimseler uğrunda harcamaları gerektiği söylenir. Dünya adamı bol rızık, iyi bir mevki ve ahiret hazırlığı olmak üzere üç şeyin peşinde koşar. Bunun için de en güzel yoldan servet kazanmak, kazandığını iyi muhafaza etmek, onu nemalandırıp artırmak ve sonra ailesiyle ve dostlarıyla ahirete de menfaat sağlayacak şekilde harcamak şeklinde dört vasıtaya ihtiyaç duyar (Beydeba, 1990: II, 144-145, 152-153).

Doğruluk; Hakikat üzere olmak, gerçeğin peşinden gitmek demektir. Bu sebeple dilsizlik, yalan söyleyen dilden daha hayırlıdır. İhtiyaç ve fakirlik de, başkalarının malıyla bolluk ve refah içinde yaşamaktan daha efdaldir (Beydeba, 1990: II, 70-73). Yalan söyleyen ve hilekârlık yapan kimse, yine kendisini aldatır. Üstelik bazı hileler sahibini öldürür ki bu yüzden, bilginler "hilekâr, ecelinden önce ölür" demişlerdir (Beydeba, 1990: I, 192-193, 240-241; II, 20-21). Suçların en büyüğü, hiçbir suçu olmayan kişiyi yalan ve jurnalcilik ile öldürmektir. Dolayısıyla görmediği halde şahitlik yapan, bilmediği şeyleri söyleyen kişinin, bilmediği şey için biliyorum demesi, felaket getirir (Beydeba, 1990: II, 22-25).

Adalet; Hükümdarların en hayırlısı insanlar arasında adaleti icra edendir (Beydeba, 1990: I, 228-229). İilik yapmaya alışmış bulunan kimseye yaptığı iş kolay gelir. O halde adaletli hâkimin yapması gereken şey, iyilik edenin fiili ile kötülük edeninkini ayırt etmektir. İyilik mükâfatla, kötülük cezayla karşılandığında, iyilik yapan daha çok iyilik yapmaya, kötülük yapan da uzak durmaya çalışır (Beydeba, 1990: II, 36-37). Bu sebeple büyüklerin "ettiğini bulursun" sözü, fiillerimizin sonuçlarına katlanmamız gerektiğini göstermektedir. Çünkü her işin günah ve sevaptan bir meyvesi vardır. Kendin için razı olmayacağın şeyi başkası için de yapmamak gerekir. Zira adalet de bundan kaynaklanır. Aynı zamanda Allah rızası ve hoşnutluğu da adalettendir (Beydeba, 1990: II, 212-213, 216-217). "Hiçbiriniz kendisi için istediğini (mü’min) kardeşi için istemedikçe (gerçek) iman etmiş olamaz." (Buhârî, Îmân, 7; Müslim, Îmân, 71).

Kanaat ve şükür; Dünyada kendini her şeyden soyutlayan, yeteri kadarıyla kanaat etmeyen, başkasının hakkına göz diken ve kendi akıbeti hakkında endişe duymayan kişi, sevgisini ve nasihatini kendisine teşekkür etmeyen birisine sarfeden tıpkı tuzlu toprağa tohum eken gibidir. Kendini beğenen kimseye görüş danışan kişi ise, ölüye danışan ya da hayvana sır veren gibidir (Beydeba, 1990: II, 220-221). Dünyada en büyük belalar ihtiras ve aç gözlülükten meydana gelir. Kanaat yani elde bulunanla yetinip memnun olmak, insan için en iyi yoldur (Beydeba, 1990: II, 70-71).

Tedbirli olmak; Kesin bir bilgi ve kanaat olmadan hüküm vermemek gerekir (Beydeba, 1990: II, 8-9). Hükümdar eğer bir kimseyi, suçunu tahkik etmeden zan üzere, anlamadan cezalandırırsa kendisini cezalandırmış ve kendisine zulmetmiş olur (Beydeba, 1990: I, 210-211). Dostluk ve düşmanlık asla bir hal üzere sebatla devam edemezler. Bazen dostluk düşmanlığa dönüşür, düşmanlık da dostluk ve arkadaşlı̆ın yerini alır. Akıllı kimse düşmanına karşı beslediği durumu, gerektiğinde bir şeyi defetmek ya da arzu edilen şeyi almak konusunda ondan yardım isteyerek değiştirebilir. Bu hususta olgunluk ve ihtiyatlı davranış gereklidir (Beydeba, 1990: II, 160-161).

Dirayet; Yöneticinin başarısı yardımcıların çokluğu ile değil, o işe elverişli olmalarıyla mümkündür. Bu açıdan insanlar dirayetli, daha dirayetli ve aciz olmak üzere üç türlüdür. Dirayetli kişi başına bir iş geldiğinde telaşeye düşmez, daha dirayetli olan kimse, musibete düşeceği şeyi önceden bilir, onu kafasında büyütür ve ona göre hazırlık yapar, çaresini arar, onunla karşılaşınca da üstesinden gelir. Aciz kişi ise, tereddüt ve oyalanma içinde olmasından dolayı helake uğrar (Beydeba, 1990: I, 168-169, 200-201).

Hilm (yumuşaklık) ve merhamet; Hükümdar mülkünü soğukkanlılık ve ağırbaşlılık ile korur. Saltanat da bunlarla ayakta durur. Hilm işlerin başıdır, hükümdarda bulunan vasıfların en güzelidir (Beydeba, 1990: II, 218-219). Akıllı kişi sakinleştiği zaman, kinin sükûnuna aldanmaz. Tahrik edici bir sebep bulamadığı zaman kinin misali yakacak odun olmadığında gizli kalan ateşe benzer. Ateşin odun araması gibi, kin de hep tahrik edici sebepleri arar. Bundan dolayı sebebi bulduğunda kin ateş gibi parlar ve güzel söz yumuşaklık, suyuna gitmek, alttan almak gibi faktörler hiçbir işe

| Kastamonu Eğitim Dergisi, 27(6), 2019| 
yaramaz (Beydeba, 1990: II, 182-183). İşte bu sebeple kinle, öfkeyle değil, akıl ve sabırla hareket etmelidir. Dolayısıyla bir hükümdarın yanında büyüklenmeyen, eziyete dayanan, öfkesini yenen, insanlara yumuşak davranan, sır saklayan kalabilir (Beydeba, 1990: I, 162-163). İyiliğin en üstünü merhamet, sevginin başı sevilene güvenmek ve dirayetin başı da olacak şeyi olmayacak şeyden ayırt etmektir (Beydeba, 1990: II, 70-71).

Cesaret; Ciddi konularda insanın çekingenlik ve merhamete sarılması doğru olmaz. Ne suçlu insanın, günahını müdafaa etmesi ne de bu suçlu kimsenin arkasında destekçi olması doğru değildir. Yine de dileğine ulaşmak için düşmana yaklaşmak gerekirse tamamen değil, biraz yaklaşmalı ki kişi korkudan ya da onun zararından emin olsun (Beydeba, 1990: II, 20-21,90-91). Cesaret erdemlerin en önemlilerinden birisidir. Bu sebeple hükümet işlerinde olduğu kadar, kişinin kararlarında ve uygulamalarında ihtiyacı olduğunda, bunu akıllıca gerçekleştirmesi gerekir. Zira ifrat ve tefrit arasında denge durumunu gözetmek, erdemin gerçekleştirilmesi bakımından önemlidir.

Dostluk; Bireysel mutluluktan ziyade toplumsal mutluluğun hedeflendiği Kelîle ve Dimne'de dostluk kavramına yapılan vurgu çok güçlüdür. Nitekim dostluk, karşılığın beklenmediği ve niyetlerin samimi olduğu hallerde gerçekleşir. İyiler arasında dostluk çabuk kurulur ve güç yıkılır. Kötüler arsındaki dostluk ise kurulması yavaş, yıkılması kolay olandır. Çünkü kötü kişi menfaat veya korku yüzünden dost olur. İnsanlar iletişim kurarken can veya malını birbirine sunmaya çalışırlar. Birbirlerini canlarını sunanlar samimi dostlar iken, mallarını sunanlar birbirinden istifade etmek isteyen birbiriyle yardımlaşan kimselerdir. İşte bu durumda canını sunmak yani dostluk, hepsinden daha değerlidir (Beydeba, 1990: II, 56-59).

İyilik ve güzel amel; İyilik manevi duygularını muhafaza eden kişiye uğrar. Çünkü iyilik, sebatkâr ve basiretli kişi için yaratılmıştr, tembel ve tereddütlü olan kimseye uğramaz. Nitekim yaz bulutu, kötü kimsenin arkadaşlığı, temelsiz bina, yalan haber, fazla servet gibi bazı şeylerde sebat yoktur. İşte bu sebeple aklı başında olan kişi servetinin azlığına üzülmez, çünkü onun serveti, aklı ve önceden yaptığı iyilikleridir (Beydeba, 1990: II, 74-75). Dünyaya düşkün kişi öldüğünde ona buradan ne mal ne dost hiç bir şey kalmaz, sadece önceden yaptığı iyi ameli kalır. Bu sebeple akıllı kişinin yanında mal kerpiç değerinde iken, kendisi için istediği iyilik ve istemediği kötülük konusunda insanların değeri, bizzat kendisinin değeri olur (Beydeba, 1990: II, 102-103). O halde günah ya da suç meselesi, yerler ve arkadaşlar bakımından değil, kalpler ve işler bakımından ele alınmalıdır. Nitekim iyi yerde olan iyi, kötü yerde olan kötü olsaydı, ibadet yerinde öldüren günahkâr, savaş meydanında sağ bırakan suç ve günah işlemiş olurdu. Bundan dolayı amellerin meyvesi önemlidir (Beydeba, 1990: II, 192-193). Güzel ahlâk güzel düşünme ve güzel uygulama ile gerçekleşir. Zira ahlâkta uygulama alanı, amellerdir.

Güzel söz; İnsanlar arasındaki en güçlü iletişim bağı, dille sağlandığı için ahlâkta, hukukta ve siyasette dilin doğru kullanılması çok önemlidir. Zira dil yarası kapanmaz, onun kestiği yaralar tedavi edilemez. Yaydan çıkan ok ete saplanır, sonra geri çekilince çıkar, fakat sözlerin oka benzeyenleri kalbe ulaşınca geri çekilemez, çıkarılamaz. Her yakıcı şeyin bir söndürücüsü vardır. Mesela ateş için su, zehir için panzehir, üzüntü için sabır, aşk için ayrılık söndürücüdür, fakat kin ateşi söndürülemez (Beydeba, 1990: II,104-105). Dil, kine götürücü amillerden kabul edildiği için dikkati elden bırakmamak, kötü sözden, dedikodudan, yalandan ve iftiradan uzak durmak gerekir.

Kişinin kendisini, dostunu ve düşmanını tanıması; Kelîle ve Dimne'ye göre, kendisini ve düşmanını tanımayan kimse helak olur. Bu sebeple akıllı kişi düşmanını küçük görmemelidir. Zira düşmanını küçümseyen kimse aldanır, düşmanına aldanan da ondan kurtulamaz. Üstün gelemeyeceği kişi ile savaşmak, insan için isabetli bir yol değildir. Bu sebeple güç yetirilemeyen düşmandan kaçmaktan başka çare yoktur. Milletlerin en temkinlisi ve en akıllısı, savaşı onda yapacağı harcamadan dolayı sevmeyendir. Çünkü savaşın dışındaki bir işte yapılan harcama servetten, sözden ve emekten ibarettir. Savaşta yapılan harcama ise canlardan ve bedenlerden ibarettir (Beydeba, 1990: II, 88-89, 92-93). Kişinin kendisine karşı sevgisi olmayan kimseden uzaklaşması kendi hayrınadır (Beydeba, 1990: II, 6-7). Akıllı kişi her işte, her durumda bütün çevresini artıran ve onlardan haberdar olan kişidir. Öyleyse bir dostun gönlünde dostuna karşı bir şüphe arız olursa, ondan korunmak konusunda intiyatlı olmalı, onu bakışlarında ve hareketlerinde tartmalıdır. Böylece kişinin tahmin ettiği doğruysa isabetli olmuş olur, doğru değilse ihtiyata sarılmış olur (Beydeba, 1990: II, 144-145).

Ahde vefa; Vefakârlıkta ecir ve erdem; sözünde durmamada ise, kötü akıbet vardır. İyi insan daima iyiliğe şükreder ve kin tutmaz. Bir tek güzel davranış, birçok kötülüğü unutturur. En çabuk verilen ceza, ahde vefa etmemenin cezasıdır. Buna göre dürüst hâkim zan ile hüküm vermemelidir, zira zan haktan yana hiçbir şeyden müstağni kalamaz (Beydeba, 1990: I, 38-39; II, 166-167). Yani gerçek olan mutlaka açığa çıkar. Bu sebeple yöneticiler ve halk için karşılıklı samimiyet ve vefa duygusunun olması gerekir. Devlet ancak sağlam görüşlü vezirler ve yardımcılar ile idare edilebilir. Onlardan da sevgi ve iyi niyetle istifade edilir (Beydeba, 1990: II, 190-191).

Basiret ve bilgelik; Kelîle ve Dimne'de kadın kocasıyla, çocuk ebeveyniyle, öğrenci hocasıyla, asker komutanıyla, ibadet yolcusu diniyle, halk hükümdarıyla, hükümdar Allah korkusuyla (takva), takva akılla, akıl tedbirli ve düşünceli davranışla kaimdir. Bütün bunların başı da basirettir. Hükümdar için basiretin başı adamlarını tanımak, derecelerine göre her birini yerlerine oturtmak, birbirlerini suçlamalarına firsat vermemektir (Beydeba, 1990: II, 204-205). Basiretli ve bilgili 
kimse iyiyi, kötüyü ve ahirete faydalı amelleri bilen, doğruyu kendisine kılavuz edinen, bundan dolayı da sevinç ve mutluluğu hak edendir. O halde iyilik ve kötülük, ceza ve sevap içinde olduğu halde kendisinden hiçbir sorumluluk hissetmeyen, gözünü haramdan, kulağını kötü şeyden, nefsini başkasına ait şeyden, kalbini nefsinin düşkünlük gösterdiği günah ve hırstan sakındırmayan kimseden uzak durmak gerekir (Beydeba, 1990: II, 244-247). İyiliğe layık olmadıkça akrabaya sırf akraba olduğu için iyilik yapmamalıdır. Yabancıdan da iyilik ve ihsanı esirgemek doğru değildir. Bu kişi belki iyiliğin şükrünü ödeyerek, iyi niyet taşıyarak, hayırla tanınarak, dosdoğru bilgili ve hayrı tercih edici olacaktır. Öyleyse kişinin yapması gereken şey, denedikten yani tecrübe ettikten sonra bir kimseyi dost edinmesidir (Beydeba, 1990: II, 258-259).

\section{Sonuç}

Ahlâk bir kişinin, bir grubun ya da toplumun eylemlerine şekil veren inanç, norm, değer, buyruk ve yasaklar bütünü olarak karşımıza çıkar. Canlılar içinde sadece insan, ahlakî varlık olma özelliğine sahiptir. Kelîle ve Dimne hayvanların dilinden ahlâkın ne olduğunu bize gösteren nadir eserlerdendir. Hükümdar çocuklarının ahlâkî bakımdan eğitilmesi için kaleme alınmakla beraber, bütün toplumu ilgilendiren ahlâkî unsurları içermektedir. Bilgece öğütlerle iyi insan ve iyi toplum olma referansı sunan eserde akıl, mutluluğun temelidir. İnsanın amaçlarını gerçekleştirmesi ve erdemlere ulaştırması için bir anahtardır. Ancak aklın iyi çalışması ve isabetli karar verebilmesi için doğru bilgiye ve basirete ihtiyacı vardır. Akıl ve bilgi, ahlâkî fiillerin kaynağı kabul edildiği için Kelîle ve Dimne, bilgelik ve erdem etiğini temsil etmekte, bu bağlamda rasyonel ahlâk ilkelerini içermektedir.

Eserde ahlâkın gayesi siyasete dayanan bireysel ve toplumsal mutluluktur. Velhasıl ahlâk siyasetten bağımsız düşünülemeyeceği için, halkın güvenliği ve mutluluğu hükümdara bağlıdır. Bu sebeple hükümdar takva, akıl, basiret, dirayet, hilm, dostluk, kardeşlik, sebat ve adalet gibi ahlâkî özelliklere sahip olmalıdır. Bununla birlikte her bireyin kendisini ve çevresini iyi tanıyarak hayatına şekil vermesi, toplumda haddi aşmadan ve ahde vefa odaklı bir yaşam sürmesi gereklidir. Nitekim birlikten kaynaklanan güçle, iyi bir eğitimle ve akılcı çözümlerle toplumun ahlâkî olarak gelişmesi ve kötülüklerden kurtulması mümkündür. Bu nitelikleri kazanma noktasında ahlâk eğitiminin küçük yaştan itibaren verilmesi ve güzel davranışların alışkanlık haline getirilmesi gereklidir. Kelîle ve Dimne'de sunulan ahlâk anlayışı Aristotelesçi erdem ahlâkıyla benzerlik göstermekte, en yüksek iyi olarak akıl, bilgi ve doğru eylem başat kabul edilmektedir. Toplumun ahlâkı bireyin ahlâkına dayandığı için, karakter eğitimi ön planda tutulmaktadır. Ahlâki fiillerdeki özgürlük konusuna gelince, Kelîle ve Dimne'de kaza ve kader insanın hayatında çok önemli olmakla birlikte, kişinin tedbiri elden bırakmaması, aceleci olmaması ve zan üzerine hüküm vermemesi gibi kişisel ve sosyal problemlerin önüne geçilebilecek uyarılara başvurulduğu görülmektedir. Bu sebeple eserde katı determinist bir yaklaşımın olmadı̆ıını; irade, tedbir ve tevekküle dayanan özgürlük anlayışının tercih edildiğini söyleyebiliriz. Ancak ahlâkta determinizmi savunan görüşe göre, akıl ve çözümleyici öneriler ya da eğitim her zaman işe yaramayabilir. Hâlbuki Kelîle ve Dimne'deki hikayeler ve mesajlar, küçük yaştan itibaren bir yöneticinin ahlâken nasıl olması gerektiğine işaret ederek, siyasi bakış açısı geliştirmekte ve eğitim odaklı çözüm önerisi sunmaktadır. Siyasetnâme ve nasihatnâme tarzında yazılması da zaten bu hususu doğrulamaktadır.

Ezcümle evrensel değerlerin oluşmasına katkı sağlayan eser, disiplinlerarası çalışmalarda meselelere farklı yaklaşımlar ve çözüm önerileri sunmak bakımından örnek teşkil etmektedir. İslâm ahlâk literatürünün ilk kaynaklarından sayılan eser, inziva hayatı ve mistik ahlâkla ilgili birkaç küçük örnek içerse de tasavvufî değil, felsefî bir renk taşımaktadır.

\section{Kaynakça}

Akarsu, B. (1998). Mutluluk Ahlâkı, İstanbul: İnıılap Yayınları.

Altaş, E. (2016). Hikemiyat Literatürü ve Ahlâk, İslâm Ahlâk Literatürü, Ankara: Nobel Yayınclık, 103-138.

Aristoteles. (2007). Nikomakhos'a Etik. (çev. Saffet Babür) Ankara: Bilgesu Yayınları.

Arslan, A. (2011). İlkçağ Felsefe Tarihi, İstanbul: i. Bilgi Üniversitesi Yayınları, c. I.

Ateş, A. (1968). ỉbnü'l-Mukaffâ, i.A, 5 (2), ìstanbul: Milli Eğitim Basımevi, 864-868.

Bakan, S. (2006). Kelîle ve Dimne'de Yer Alan Masalların Dinî ve Ahlâkî Eğitime Katkıları, Yayınlanmamış Yüksek Lisans Tezi, Atatürk Üniversitesi, Erzurum.

Berkowitz, M. W. (2014). Karakter Eğitimi Bilimi. (çev. Macid Yılmaz), Din Bilimleri Akademik Araştırma Dergisi, 14 (3), $285-302$.

Beydeba. (1990). Kelîle ve Dimne. (çev. Topaloğlu, B.-Karaman, H). İstanbul: Fatih Yayınevi, c.l-II.

Brockelmann, C. (1977). Kelîle ve Dimne, i.A. İstanbul: Milli Eğitim Basımevi, c.6, 552-558.

Çağrıcı, M. (1989). Ahlâk, DíA, ìstanbul: TEDAV, c.2, 1-9.

Fahri, M. (1992). İslam Felsefesi Tarihi (A History of İslamic Philosophy). (çev. Kasım Turhan) isstanbul: íklim Yayınları.

(2016). İslâm Ahlâk Teorileri (Ethical Theories in İslam). (çev. Muammer İskenderoğlu-Atilla Arkan) İstanbul: Litera Yayıncilık.

| Kastamonu Eğitim Dergisi, 27(6), 2019| 
Duran E., Ercan E. (2018). Fablların Değer Eğitimindeki Önemi Gelecek Vizyonlar Dergisi, 2(1), 31-43.

Gutas, D. (1981), Classical Arabic Wisdom Literature Nature and Scope, Journal of the American Oriental Society, 101/1, 49-86.

İbn Miskeveyh. (2017). Tertîbu's-Saâdât ve Menâzilu'I-Ulûm. (çev. Hümeyra Özturan), (nşr. Hümeyra Özturan), İstanbul: Klasik Yayınları.

İbn Mukaffa. (1990). Kitabın Hedefi, Kelîle ve Dimne içinde, İstanbul: Fatih Yayınevi, 93-117.

İbn Sehevân. (1990). Kitabın Önsözü, Kelîle ve Dimne içinde, İstanbul: Fatih Yayınevi, 7-55.

İbn Sînâ. (1989). Fî Aksâmi'l-Ulûmi'l-Akliyye, Tis'u Resâil, Kahire: Dâru'l-Arab.

Karaismailoğlu, A. (2002). Kelîle ve Dimne, DiA, İstanbul: TEDAV, c.25, 210-212.

Kınalızâde. (2012). Ahlâk-ı Alâ'î. (haz. Mustafa Koç), İstanbul: Klasik Yayınları,

Kutluer, ì. (2000), İbnü'l-Mukaffa, DiA, Ankara: TEDAV, c.21, 134-137.

Kuzudişli, A. (2017). İbnü'l-Mukaffa ve İslâmi İlimlerin Oluşumundaki Rolü, Türk ve İslâm Dünyası Sosyal Araşttrmalar Dergisi, 4 ( 12), 51-61.

Nasîrüddin Tûsî. (2007). Ahlâk-ı Nâsırî. (çev. Anar Gafarov, Zaur Şükürov) (ed. Tahir Özakkaş), İstanbul: Litera Yayıncılık.

Orak, K.-Berköz, M. (2013). Kelîle ve Dimne Tercümeleri ve Kitlelerin Eğitimindeki Rolü, Türkiyat Mecmuası, 23(Güz), $207-232$.

Özlem, D. 2010, Etik Ahlâk Felsefesi, İstanbul: Say Yayınları.

Özturan, H. (2015). Ahlâk Felsefesinin Temel Problemleri, Ankara: Nobel Yayınları.

Pattabanoğlu, F. Z. (2018). Taşköprîzâde'de Felsefenin Pratik Alanı Olarak Ahlâk, ÇAKÜ Sosyal Bilimler Enstitüsü Dergisi, 9 (1), $122-$ 142.

Platon. (2010). Sokrates'in Savunması. (çev. Özgü Çelik) İstanbul: Say Yayınları.

Saruhan, M. S. (2002). Ahlâk Felsefemizde İyi ve Kötünün Sebepleri, İslâmî Araştırmalar, 15(4), 543-558.

Taşköprîzâde. (1968). Miftâhu's-Saâde ve Misbâhu's-Siyâde fî Mevzuâti'l-Ulûm. (thk. Kamil Bekri, Abdülvehhab Ebü’n-Nur), Kahire: Dârü'I-Kütübi'l-Hadise, c.I.

(2014). Şerhu'I-Ahlâki'l-Adudiyye. (çev. Müstakim Arıcı) (ed. Ömer Türker, Metin: Elzem İçöz-Müstakim Arıcı), İstanbul: TYEKB Yayınları.

(2016). Risâle fî Fazîleti Mekârimi'l-Ahlâk. (Ahlâk ve Siyaset Risaleleri içinde). (çev. Müstakim Arıcı), (thk. Müstakim Arıcı), İstanbul: i. Medeniyet Ü. Yayınları.

Topaloğlu, B.-Karaman, H. (1990). Eser Hakkında Birkaç Söz, Kelîle ve Dimne içinde, İstanbul: Fatih Yayınevi, 3-5.

Toska, Z. (1989). Türk Edebiyatında Kelîle ve Dimne Çevirileri ve Kul Mesûd Çevirisi, Yayınlanmamış Doktora Tezi, İstanbul Üniversitesi, İstanbul.

(1991). Kelîle ve Dimne'nin Türkçe Çevirileri, TUBA, 15, 355-377.

Turhan, K. (1996). Kelam ve Felsefe Açısından İnsan Fiilleri, İstanbul: İFAV Yayınları.

Uçar, A. (2012). Osmanlı Siyaset-Yönetim Düşün Geleneği: Daire-i Adalet'in Yönetimi, Memleket Siyaset Yönetim, 7 (17), 1-33. 